\title{
Effect of 9-cis retinoic acid and all-trans retinoic acid in combination with verapamil on P-glycoprotein expression in L1210 cells
}

\author{
A. BREIER ${ }^{1,2, *}$, J. STETKA ${ }^{2}$, V. BOHACOVA ${ }^{2}$, D. MACEJOVA ${ }^{3}$, J. BRTKO ${ }^{3}$, Z. SULOVA ${ }^{2, *}$ \\ ${ }^{1}$ Institute of Biochemistry, Nutrition and Health Protection, Faculty of Chemical and Food Technology, Slovak University of Technology, Radlinskeho \\ 9, 81237 Bratislava, Slovak Republic; ${ }^{2}$ Institute of Molecular Physiology and Genetics, Slovak Academy of Sciences, Vlarska 5, 83334 Bratislava, \\ Slovak Republic; ${ }^{3}$ Institute of Experimental Endocrinology, Slovak Academy of Sciences, Vlarska 3, 83306 Bratislava, Slovak Republic
}

*Correspondence: albert.breier@stuba.sk,zdena.sulova@savba.sk

Received November 29, 2013 / Accepted February 11, 2014

\begin{abstract}
The development of the most common multidrug resistance (MDR) phenotype is associated with a massive overexpression of P-glycoprotein (P-gp) in neoplastic cells. In the current study, we used three L1210 cell variants: S cells - parental drugsensitive cells; R cells - drug-resistant cells with P-gp overexpression due to selection with vincristine; T cells - drug-resistant cells with P-gp overexpression due to stable transfection with the pHaMDRwt plasmid, which encodes human full-length P-gp. Several authors have described the induction of P-gp expression/activity in malignant cell lines after treatment with all-trans retinoic acid (AtRA; ligand of retinoic acid nuclear receptors, RARs). An isomer of AtRA also exists, 9-cis retinoic acid, which is a ligand of both RARs and nuclear retinoid X receptors (RXRs). In a previous work, we described that the combined treatment of $\mathrm{R}$ cells with verapamil and AtRA induces the downregulation of P-gp expression/activity. In the current study, we studied the expression of RARs and RXRs in S, R and T cells and the effects of treatment with AtRA, 9cRA and verapamil on P-gp expression, cellular localization and efflux activity in $\mathrm{R}$ and $\mathrm{T}$ cells. We found that the overexpression of P-gp in L1210 cells is associated with several changes in the specific transcription of both subgroups of nuclear receptors, RARs and RXRs. We also demonstrated that treatment with AtRA, 9cRA and verapamil induces alterations in P-gp expression in $\mathrm{R}$ and $\mathrm{T}$ cells. Particularly, combined treatment of $\mathrm{R}$ cells with verapamil and AtRA induced downregulation of P-gp content/activity. In contrast, similar treatment of T cells induced slight increase of P-gp content without any changes in efflux activity of this protein. These findings indicate that active crosstalk between the RAR and RXR regulatory pathways and P-gp-mediated MDR could take place.
\end{abstract}

Key words: P-glycoprotein, all-trans retinoic acid, 9-cis retinoic acid, retinoic acid nuclear receptors, retinoid X receptors, verapamil

Nuclear retinoic acid receptors (RARs) and retinoid $\mathrm{X}$ receptors (RXRs; also known as rexinoid receptors) are ligand-activated DNA-binding proteins that are involved in the transcriptional control of target genes $[8,9]$. Their ligands (retinoids) include naturally occurring and synthetic metabolites and analogs of vitamin A [18]. RXRs are activated by 9-cis-retinoic acid (9cRA) and regulate transcription as either a homodimer or a heterodimer with numerous other nuclear receptors, including RARs $[12,48]$. While 9cRA can activate both RXRs and RARs, another vitamin A analog, all-trans retinoic acid (AtRA), is known to interact exclusively with RARs [18] and induces important effects on cell development, proliferation and differentiation, and these effects are mediated by the specific regulation of transcription induced by retinoid: rexinoid nuclear receptor heterodimers [10]. An assortment of retinoic acid-induced pathways are linked with the existence of at least three subtypes of nuclear receptors for all-trans retinoic acid, RAR $\alpha, \beta$ and $\gamma$, and three subtypes of nuclear receptors for 9-cis retinoic acid, RXR $\alpha, \beta$ and $\gamma$, which have distinct amino- and carboxy-terminal domains (reviewed in $[8,40]$ ). Cell differentiation and subsequent apoptosis in several types of malignant cells with immature phenotypes are known to be induced by AtRA [54]. AtRA alone or in combination with other agents has been described to induce differentiation and apoptosis in HL60 cells $[19,42,55]$. Clinically, AtRA has been approved for the treatment of patients with acute promyelocytic leukemia (APL) $[1,25]$. The intracellular concentration of AtRA is properly controlled through interactions between 
enzymes involved in AtRA biosynthesis (retinol and retinal dehydrogenases) and retinoid binding-proteins, with feedback control of AtRA occurring through the regulation of the gene expression of multiple participants in this process [26]. Another mechanism by which the intracellular AtRA concentration is regulated involves the mediation of its metabolism by members of the cytochrome P450 (CYP) gene family. The predominant role in AtRA metabolism is played by CYP26, which is transcriptionally controlled by RARs [32], and by members of the CYP3A gene subfamily. The transcription of CYP3A is regulated by pregnane $\mathrm{X}$ nuclear receptor (PXR) and is activated by various substances, including chemotherapeutic agents that are often used in combination with AtRA in the treatment of APL [53]. PXR provides its transcriptional control after dimerization with RXR [20, 22].

With respect to cancer therapy, several lines of evidence have shown that retinoids are involved in the development of multidrug resistance (MDR) via the activation of RAR and RXR, particularly the MDR subtype that is mediated by the membrane transporter P-glycoprotein (P-gp) [16]. P-glycoprotein is a drug efflux ATPase that was classified as ABCB1 member of the $\mathrm{ABC}$ transporter gene family, and shows broad specificity to diverse groups of substances, including anthracyclines (e.g., doxorubicin), vinca alkaloids (e.g., vincristine - VCR), actinomycines (e.g., actinomycin D, dactinomycines), taxols (e.g., paclitaxel), alkylating agents (e.g., mytomycin C), peptide antibiotics (e.g., gramicidin, valinomycin), and many others $[5,6]$.The transcription of P-gp is controlled by PXR and other nuclear receptors that are dimerization partners of RXR [33]. Since 1989, when Bates et al. [2] described the upregulation of P-gp at both the mRNA and protein level after the treatment of neuroblastoma cell lines with retinoic acid, relatively little knowledge has been gained on the effects of RAR ligands on P-gp-mediated MDR development. Moreover, the increase in P-gp expression described by Bates did not lead to changes in the intracellular accumulation of VCR, a P-gp substrate. The treatment of APL patients with AtRA alone or in combination with anticancer drugs induces resistance against subsequent treatment with this substance [13]. A weak increase in P-gp expression has been shown to accompany the development of AtRA resistance in several cell models [47]. The treatment of monocytic leukemia cells with AtRA induces the expression of P-gp [51]. However, the efflux activity of Pgp is not responsible for the depressed sensitivity of cells to AtRA because this substance is not a substrate of P-gp [38]. Nevertheless, the increase of P-gp expression observed after the treatment of cells with AtRA in combination with other therapeutic agents, such as histone deacylase depsipeptide inhibitor (HDACI), may lead to cross resistance to P-gp substrates, such as doxorubicin [44]. In a previous study, we examined the effects of AtRA on P-gp expression/function [38] using a P-gp-negative parental L1210 cell line (S) and its $\mathrm{P}$-gp overexpression variant $(\mathrm{R})$, which was obtained by the adaptation of S cells to VCR [31]. While AtRA alone did not alter P-gp expression or activity in the R cells, the combined treatment of the R cells with both verapamil (VER; inhibitor of P-gp and several members of the CYP family) and AtRA induced a decrease in both the P-gp protein content and P-gp activity [38]. The combination of AtRA and VER may induce this effect by impeding P-gp transcription or inducing alterations in post-transcriptional modifications of $\mathrm{P}$-gp that could lead to an acceleration of P-gp degradation. To examine this hypothesis, we aimed to study the effects of combined treatment with VER and AtRA on the expression of P-gp at the mRNA and protein level and the P-gp efflux activity in $\mathrm{R}$ cells as well as in another P-gp-positive L1210 cell variant (T), in which the expression of P-gp is induced by the stable transfection of the P-gp gene [39]. We also analyzed the effects of another isomer of retinoic acid, 9cRA, alone and in combination with VER, on the expression and efflux activity of P-gp in R and T cells.

\section{Materials and methods}

Cell culture. The following L1210 cell variants were used in this study: (i) $\mathrm{S}$ - drug-sensitive parental cells; (ii) $\mathrm{R}$ - Pgp-positive, drug-resistant cells that overexpress $\mathrm{P}$-gp due to selection with VCR (Gedeon Richter Co., Hungary) [31]; and (iii) $\mathrm{T}$ - P-gp-positive, drug-resistant cells that overexpress $\mathrm{P}$ gp due to the stable transfection of the P-gp gene [39] using the Addgene plasmid 10957 (pHaMDRwt), a retrovirus that encodes the full-length P-gp cDNA [30]. The cells ( $\mathrm{S}, \mathrm{R}$ and T; $1 \times 10^{6}$ cells) were cultured in $4 \mathrm{ml}$ RPMI 1640 medium with L-glutamine $(1 \mathrm{mg} / \mathrm{ml}), 4 \%$ fetal bovine serum and $1 \mu \mathrm{g} / \mathrm{ml}$ gentamycin (all purchased from Gibco, USA) in a humidified atmosphere with $5 \% \mathrm{CO}_{2}$ and at $37^{\circ} \mathrm{C}$. The R cells were cultured for two passages without VCR prior to each experiment. All three L1210 cell variants were cultivated in the absence or presence of AtRA alone $(3.3 \mu \mathrm{mol} / \mathrm{l}), 9 \mathrm{cRA}$ alone $(3.3 \mu \mathrm{mol} / \mathrm{l})$, VER $(10 \mu \mathrm{mol} / \mathrm{l})$ alone, AtRA in combination with VER or 9cRA in combination with VER. After cultivation, the cells were used in the following experiments.

Effect of AtRA on cell viability. Cells (S, R and T) were cultivated (by the same procedure described previously in the absence or presence of AtRA, 9cRA (both at a concentration range of $0.033-3.300 \mu \mathrm{mol} / \mathrm{l})$ and $\mathrm{VCR}(0.2 \mu \mathrm{mol} / \mathrm{l})$. All experiments with AtRA and 9cRA were performed under limited light conditions. The final concentrations of AtRA and 9cRA were adjusted by the addition of the appropriate volume of a stock solutions of $3.3 \mathrm{mmol} / \mathrm{l}$ AtRA in ethanol directly to the cultivation medium. This medium $(200 \mu \mathrm{l}$ per well in 96 well tissue plates) was inoculated with $\mathrm{S}, \mathrm{R}$, or T cells $\left(5 \times 10^{4}\right.$ cells). After $48 \mathrm{~h}$ of culture, the viability of the cells was tested by MTT assay [14].

Determination of the mRNA levels of the RAR and RXR isomers and P-gp in S, R and T cells. Total RNA was isolated from the $S, R$ and $T$ cells using TRIzol reagent (Life Technology, Slovakia) according to the manufacturer's instructions. Reverse transcription (RT) was performed with $2 \mu \mathrm{g}$ of total DNAse I (Thermo Scientific, Germany)-treated 
RNA and the RevertAidTM H Minus First Strand cDNA Synthesis Kit (Thermo Scientific, Germany) according to the manufacturer's protocol. PCR was performed in a total volume of $25 \mu \mathrm{l}$ consisting of $4 \mu \mathrm{l}$ RT mixture, 1x PCR buffer, $1.5 \mathrm{mmol} / \mathrm{l} \mathrm{MgCl} 2,0.2 \mathrm{mmol} / \mathrm{l} \mathrm{dNTP}, 1 \mathrm{pmol}$ of each specific gene primer set and $0.3 \mathrm{U}$ of DyNAzyme II DNA polymerase (Finnzymes OY, Finland) in the buffer provided by the manufacturer. After treating the samples at $94^{\circ} \mathrm{C}$ for $3 \mathrm{~min}$ to inactivate the reverse transcriptase, they were subjected to 35 cycles of denaturation $\left(95^{\circ} \mathrm{C}, 45 \mathrm{sec}\right)$, annealing $\left(57^{\circ} \mathrm{C}\right.$, 30 sec- P-gp from Mus musculus and Homo sapiens; $58^{\circ} \mathrm{C}$, 30 sec- GAPDH, RAR $\alpha, \operatorname{RAR} \beta$, RAR $\gamma ; 60^{\circ} \mathrm{C}, 30 \mathrm{sec}-\mathrm{RXR} \alpha$, $\operatorname{RXR} \beta, \operatorname{RXR} \gamma)$, and extension $\left(72^{\circ} \mathrm{C}, 90 \mathrm{sec}\right)$ and then a final extension at $72^{\circ} \mathrm{C}$ for $10 \mathrm{~min}$. The PCR products were separated on a $1.7 \%$ agarose gel (Invitrogen, Life Technology, Slovakia), and specific bands were visualized using ethidium bromide with a Typhoon 9210 imaging system (GE Healthcare, USA, formerly Amersham Biosciences) and normalized to the band intensity of GAPDH.

Semiquantitative real-time PCR was performed in a total volume of $20 \mu \mathrm{l}$ using Maxima SYBR Green/ROX qPCR Master Mix (2x) (Thermo Scientific, Germany) and $250 \mathrm{nmol} / \mathrm{l}$ of each primer. Amplification and detection were performed with an ABI Prisma 7900HT detection system (Applied Biosystems, USA) under the following conditions: $95^{\circ} \mathrm{C}$ for $10 \mathrm{~min}, 40$ cycles of denaturation $\left(95^{\circ} \mathrm{C}, 15 \mathrm{sec}\right)$, annealing $\left(57^{\circ} \mathrm{C}, 30 \mathrm{sec}\right.$ - P-gp from Mus musculus and Homo sapiens; $58^{\circ} \mathrm{C}, 30 \mathrm{sec}-$ GAPDH, RAR $\alpha, \operatorname{RAR} \beta, \mathrm{RAR} \gamma ; 60^{\circ} \mathrm{C}, 30 \mathrm{sec}-\mathrm{RXR} \alpha, \mathrm{RXR} \beta$, $\mathrm{RXR} \gamma)$, and extension $\left(72^{\circ} \mathrm{C}, 30 \mathrm{sec}\right)$ and the a final melting curve analysis. The sequences of the primers employed in this study are as follows: GAPDH, F: $5^{\prime}$-TGA ACG GGA AGC TCA CTG G-3', R: 5' -TCC ACC ACC CTG TTG CTG TA-3'; P-gp from Mus musculus, F: 5 '-GGC TGT TAA AGG TAA CTC C3', R: 5' -TGT TCT CTT ATG AAT CAC GTA-3'; P-gp from Homo sapiens, F:5'-AGA CAT GAC CAG GTA TGC-3', R: 5' - CTC CTG TCG CAT TAT AGC-3'; RAR $\alpha$, F:5' -CAG ATG CAC AAC GCT GGC-3', R: 5'-CCG ACT GTC CGC TTA GAG-3; RAR $\beta$, F: $5^{\prime}$-ATG CTG GCT TCG GTC CTC-3' ${ }^{\prime}$ R: 5'-CTG CAG CAG TGG TGA CTG-3'; RAR $\gamma$, F: 5' -GTG GAG ACC GAA TGG ACC-3', R:5'-GAC AGG GAT GAA CAC AGG-3'; RXR $\alpha$, F: 5' -ACA TGC AGA TGG ACA AGA CG-3', R:5'-GGG TTT GAG AGC CCC TTA GA-3'; RXR $\beta$ , F: 5'-GTT CTT CCA TGG GGT CTC CT-3', R:5'-GGA GCG ACA CTG TGG AGT TAA T-3'; and RXR $\gamma$, F: $5^{\prime}$-TTG GAA TGG CTC AAA CCA C-3', R: ${ }^{\prime}$-AGG GCT GGG CAC TAT CTC TT- ${ }^{\prime}$. The data are expressed as the relative level of each mRNA normalized to that of the housekeeping gene GAPDH.

Determination of the P-gp level in $S, R$ and $T$ cells by western blot analysis. After incubation, the cells were harvested, and crude membrane fractions were prepared with a ProteomeExtract Subcellular Proteome Extraction Kit (Calbiochem, USA) according to the manufacturer's instructions. The proteins from the samples were separated by sodium dodecyl sulfate-polyacrylamide electrophoresis (SDS-PAGE) using $8 \%$ polyacrylamide gels. The proteins were then transferred by electroblotting to a nitrocellulose membrane. P-gp was detected using the c219 anti-P-gp monoclonal antibody (Calbiochem, USA). A secondary anti-mouse antibody conjugated to horseradish peroxidase (GE Healthcare, USA) was used for detection. To provide an internal control for protein loading, a rabbit polyclonal antibody against GAPDH (Santa Cruz Biotechnology, USA), was used as a primary antibody, and goat anti-rabbit IgG conjugated to horseradish peroxidase (Santa Cruz Biotechnology, USA) served as a secondary antibody. The protein bands were visualized using an ECL detection system (GE Healthcare, USA) and a CF 440 imaging system (Kodak, USA).

Visualization of P-gp in $S, R$ and T cells by immunofluorescence confocal microscopy. After cultivation, the cells were washed, resuspended in PBS, and transferred onto poly-L-lysine cover glasses (Menzel Glaser, Germany). The bound cells were washed twice with PBS and then fixed and permeabilized with methanol at $-20^{\circ} \mathrm{C}$ for $20 \mathrm{~min}$. The cells were again washed with $\mathrm{PBS}$ and then blocked by incubation with $1 \% \mathrm{BSA}$ in $\mathrm{PBS}$ for $1 \mathrm{~h}$ at $37^{\circ} \mathrm{C}$. Next, they were incubated with the 2219 anti-P-gp antibody for $1 \mathrm{~h}$ at $37^{\circ} \mathrm{C}$ in PBS containing $1 \%$ BSA. After the primary antibody incubation, the cells were washed twice with PBS containing $1 \%$ BSA. Then, the cells were incubated with FITC-conjugated goat anti-mouse antibody (Calbiochem, USA) in PBS containing $1 \% \mathrm{BSA}$ for $1 \mathrm{~h}$ at $37^{\circ} \mathrm{C}$ and then washed twice in PBS containing $1 \%$ BSA. Finally, the coverslips were mounted onto slides with a mounting medium ( $80 \%$ glycerol) and analyzed using a confocal laser scanning microscope (LSM 510 META; Carl Zeiss, Germany).

Examination of P-gp function by calcein/AM assay. To remove VER, after cultivation, the $\mathrm{S}, \mathrm{R}$ and $\mathrm{T}$ cells were collected by centrifugation $(500 \times \mathrm{g})$ and washed three times with PBS containing $0.2 \% \mathrm{BSA}$. The washing procedure included three, 10-min incubations of the cells in buffer eliminate any VER retained in the cells. Then, the cells were resuspended in $500 \mu \mathrm{l}$ of the same buffer. Calcein/AM (final concentration of $0.1 \mu \mathrm{mol} / \mathrm{l}$; Sigma-Aldrich) and propidium iodide (final concentration of $0.9 \mu \mathrm{mol} / \mathrm{l}$ ) were added directly to the buffer, and the samples were incubated for $20 \mathrm{~min}$ at $37^{\circ} \mathrm{C}$. After incubation, the cells were washed twice with ice cold PBS. Fluorescence was measured using an Accuri C6 flow cytometer (BD Bioscience, USA).

Statistical analysis. The data are expressed as the means $( \pm$ SD). Statistical significance was assessed using ANOVA with Bonferroni or Tukey's post-hoc tests.

\section{Results}

Effect of AtRA and 9cRA on cell death in S, R and $T$ cells. The cytotoxic effects of both retinoic acid isomers in $\mathrm{S}, \mathrm{R}$ and T cells were evaluated by MTT assay. While AtRA alone induced a slight but significant increase in cell death in the S (27\%), R (15\%) and T (15\%) cells at a concentration 
$3.3 \mu \mu \mathrm{mol} / \mathrm{l}$, 9cRA alone failed to induce cell death (Fig. 1). When AtRA or 9cRA were applied together with VCR $(0.2 \mu \mathrm{mol} / \mathrm{l})$ the viabilities of the $\mathrm{R}$ and $\mathrm{T}$ cells were decreased by $20 \%$. This concentration of VCR was previously shown to induce massive cell death in $S$ cells but a measurable increase in cell death was not observed in $\mathrm{R}$ and $\mathrm{T}$ cells [11].

Effect of AtRA or 9cRA alone and in combination with VER on the expression of RARs and RXRs in $S, R$ and $T$ cells. The mRNA expression levels of the RAR and RXR isoforms in the $\mathrm{S}, \mathrm{R}$ and $\mathrm{T}$ cells were analyzed by reverse transcription
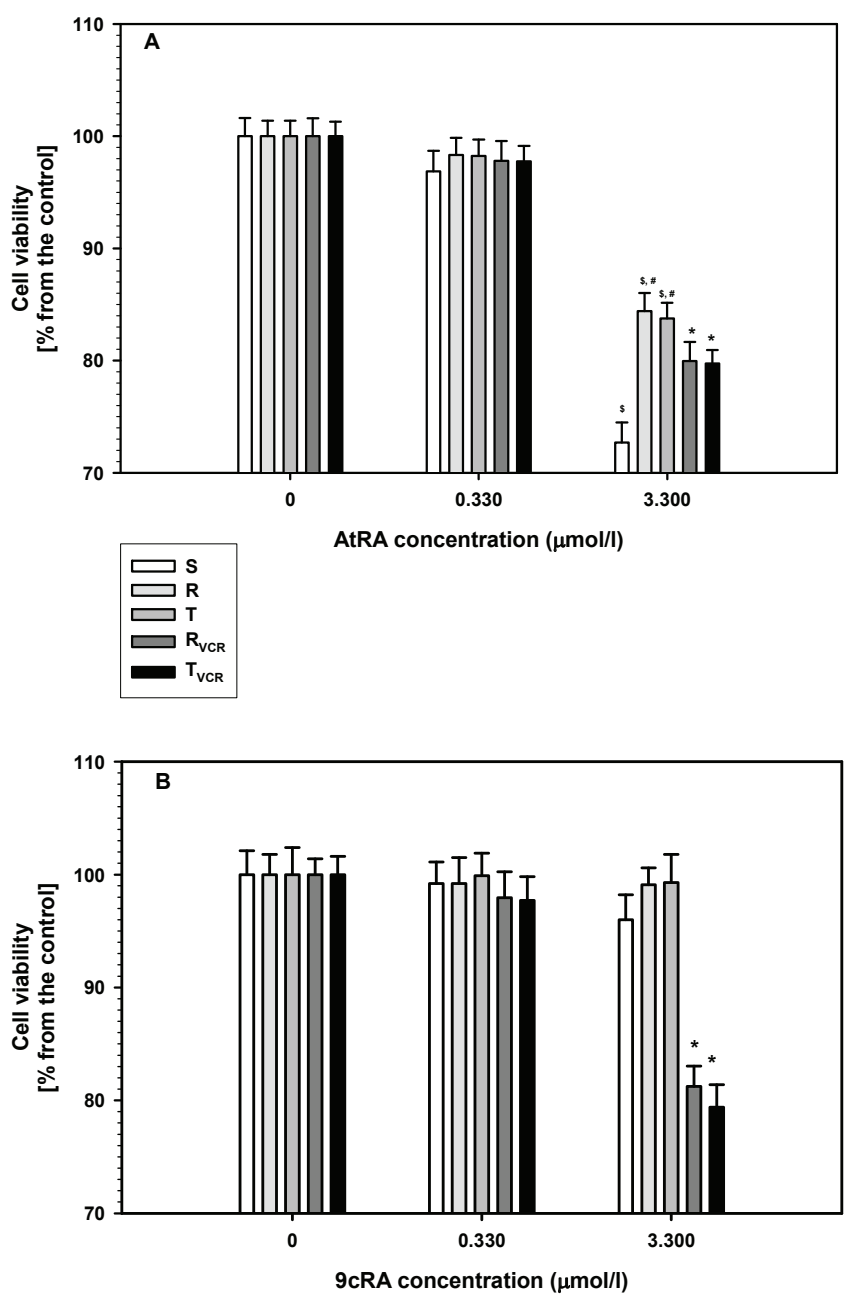

Figure 1. Cell death effects of AtRA (Panel A) and 9cRA (Panel B) on S, $R$ and $T$ cells. The cells were cultivated in the absence or presence of AtRA or 9cRA at the indicated concentrations for 48 hours. $R$ and $T$ cells were subjected to combined treatment with VCR $(0.2 \mu \mathrm{mol} / \mathrm{l})$ and each retinoic acid isomer. After cultivation, the cell viabilities were ascertained by MTT assay (for details, see the Material and Methods section). Data represent the means $\pm S_{D}$ of six independent measurements. Statistical significance: \$ - value differs from corresponding value in the absence of AtRA at $p<0.02$; \# - value differs from $S$ cells at the AtRA concentration of $3.3 \mu \mathrm{mol} / \mathrm{l}$ at $\mathbf{p}<0.02{ }^{*}$ - value differs from the corresponding value obtained for $\mathrm{R}$ and T cells treated with $3.3 \mu \mathrm{mol} / 1$ of AtRA or $9 \mathrm{cRA}$ but in the absence of VCR at $\mathbf{p}<0.05$.
PCR. A strong elevation of RXRa transcripts in the R cells compared with $\mathrm{S}$ or $\mathrm{T}$ cells was observed (Fig. 2, panel A). For better quantification of the mRNA levels of the RAR and RXR isoforms, quantitative reverse transcription PCR was performed using the same primers.

The expression of RARa was significantly higher in the $\mathrm{T}$ cells than the $\mathrm{S}$ cells $(\mathrm{p}<0.05$; Fig. $2, \mathrm{RAR} \alpha)$. A small and insignificant increase in the level of this transcript was also visible in the $\mathrm{R}$ cells when compared with the $\mathrm{S}$ cells. VER alone significantly reduced expression of RARa in all cell lines when compared to the respective untreated control cells $(\mathrm{p}<0.05, \mathrm{~S}$ cells and $\mathrm{p}<0.001, \mathrm{R}$ and T cells; Fig. 2, RAR $\alpha)$. The treatment of the $S$ and $R$ cells with AtRA induced a significant elevation of the RAR $\alpha$ mRNA content ( $p<0.001$; Fig. 2, RAR $\alpha$ ). An increase in this transcript was also visible in the AtRAtreated $\mathrm{T}$ cells, but this change was not statistically significant. VER induced the downregulation of RAR a expression in the $S$, $\mathrm{R}$ and $\mathrm{T}$ cells also when applied together with AtRA ( $\mathrm{p}<0.05$; Fig. 2, RARa). However, mRNA level of RARa in cells treated with AtRA and VER was still significantly higher than that in cells treated with VER alone ( $p<0.01$; Fig. 2, RAR $\alpha$ ). Similar to the result observed after AtRA treatment, treatment with 9cRA induced an increase in the RARa mRNA level in the $S$ and $\mathrm{R}$ cells when compared to the untreated control cells $(\mathrm{p}<0.05$; Fig. 2, RARa). Simultaneous treatment with 9cRA and VER reduced the levels of RAR $\alpha$ in the $R$ and $T$ cells $(p<0.01$ and $\mathrm{p}<0.05$, respectively; Fig. 2, RAR $\alpha$ ) but not in the $S$ cells when compared with treatment with 9cRA alone.

RAR $\beta$ was present at a similar level in the $S$ and $R$ cells (Fig. 2, RAR $\beta$ ). However, transfection with human P-gp in the T cells was associated with a significant reduction of the RAR $\beta$ transcript in comparison with the $S$ and $R$ cells ( $p<0.01$; Fig. 2, RAR $\beta$ ). VER alone inhibited the expression of this transcript in the $S$ cells ( $p<0.01$ vs. untreated cells; Fig. 2 , RAR $\beta$ ) but not in the R or T cells. While the treatment of the cells with AtRA alone or in combination with VER failed to significantly affect the RAR $\beta$ mRNA level, 9cRA induced its expression in all the L1210 cell variants examined in this study (at least at $\mathrm{p}<0.05 \mathrm{vs}$. untreated cells; Fig. 2, RAR $\beta$ ). Combined treatment with both 9cRA and VER reduced the expression of this RAR isoform in the $\mathrm{R}$ and $\mathrm{T}$ cells $(\mathrm{p}<0.05$; Fig. 2 , RAR $\beta$ ) but not in the $\mathrm{S}$ cells when compared to the 9cRA-treated cells.

The expression of RAR $\gamma$ was significantly higher in both $\mathrm{P}$-gp-positive cell variants ( $\mathrm{R}$ and $\mathrm{T}$ ) than in the P-gp-negative $S$ cells ( $\mathrm{p}<0.001$; Fig. $2, \mathrm{RAR} \gamma$ ). VER alone did not affect the RAR $\gamma$ mRNA level in the $S$ cells but significantly reduced this transcript in the R and T cells ( $\mathrm{p}<0.001$; Fig. $2, \mathrm{RAR} \gamma$ ) when compared to the respective untreated control cells. Treatment with AtRA or 9cRA significantly elevated the mRNA expression of RAR $\gamma$ in all cell variants compared with their untreated counterparts ( $\mathrm{p}<0.001$; Fig. 2, RAR $\gamma$ ). The highest increase in RAR $\gamma$ expression induced by AtRA was observed in the T cells $(\mathrm{p}<0.001)$. Treatment with VER together with each retinoic acid isomer did not significantly alter the levels of the RAR $\gamma$ transcript from those detected after treatment with AtRA or 
9cRA alone in the S and R cells. However, in the T cells, a lower level of this transcript was found after combined treatment with VER and AtRA than after treatment with AtRA alone $(\mathrm{p}<0.001$; Fig. 2, RAR $\gamma)$. Conversely, the treatment of T cells with VER and 9cRA induced a more pronounced elevation in RAR $\gamma$ gene transcription than the treatment of this cell variant with 9cRA alone ( $\mathrm{p}<0.05$; Fig. 2, RAR $\gamma$ ).

At least a three-fold higher level of RXRa was found in the $R$ cells compared to the $S$ and $T$ cells $(p<0.001$; Fig. 2, $\mathrm{RXR} \alpha$ ). However, the expression of this receptor subtype was significantly lower in the $\mathrm{T}$ cells than in the $\mathrm{S}$ cells $(\mathrm{p}<0.01$; Fig. 2, RXRa). VER alone had no effect on the mRNA level of RXRa in all the studied variants of L1210 cells. In the $S$ cells, AtRA reduced the levels of the RXR $\alpha$ transcript ( $p<0.05$; Fig.
2, RXRa).Conversely, in both P-gp-positive cell variants, treatment with AtRA did not significantly alter the transcription of this nuclear receptor. However, when AtRA was used together with VER to treat the S, R and T cells, increases in the transcription of this receptor compared to treatment with AtRA alone were observed in each case ( $\mathrm{p}<0.05$; Fig. $2, \mathrm{RXR} \alpha)$. In the $\mathrm{R}$ cells, treatment with 9cRA resulted in an elevation of RXRa expression when compared to the untreated control cells $(\mathrm{p}<0.01$; Fig. $2, \mathrm{RXR} \alpha)$. In contrast, no changes in the expression of this nuclear receptor subtype were observed in the $\mathrm{S}$ or $\mathrm{T}$ cells after treatment with $9 \mathrm{cRA}$. Treatment with VER together with 9cRA did not significantly alter the levels of the RXRa transcript when compared with 9cRA alone in all L1210 cell variants (Fig. 2, RXRa).
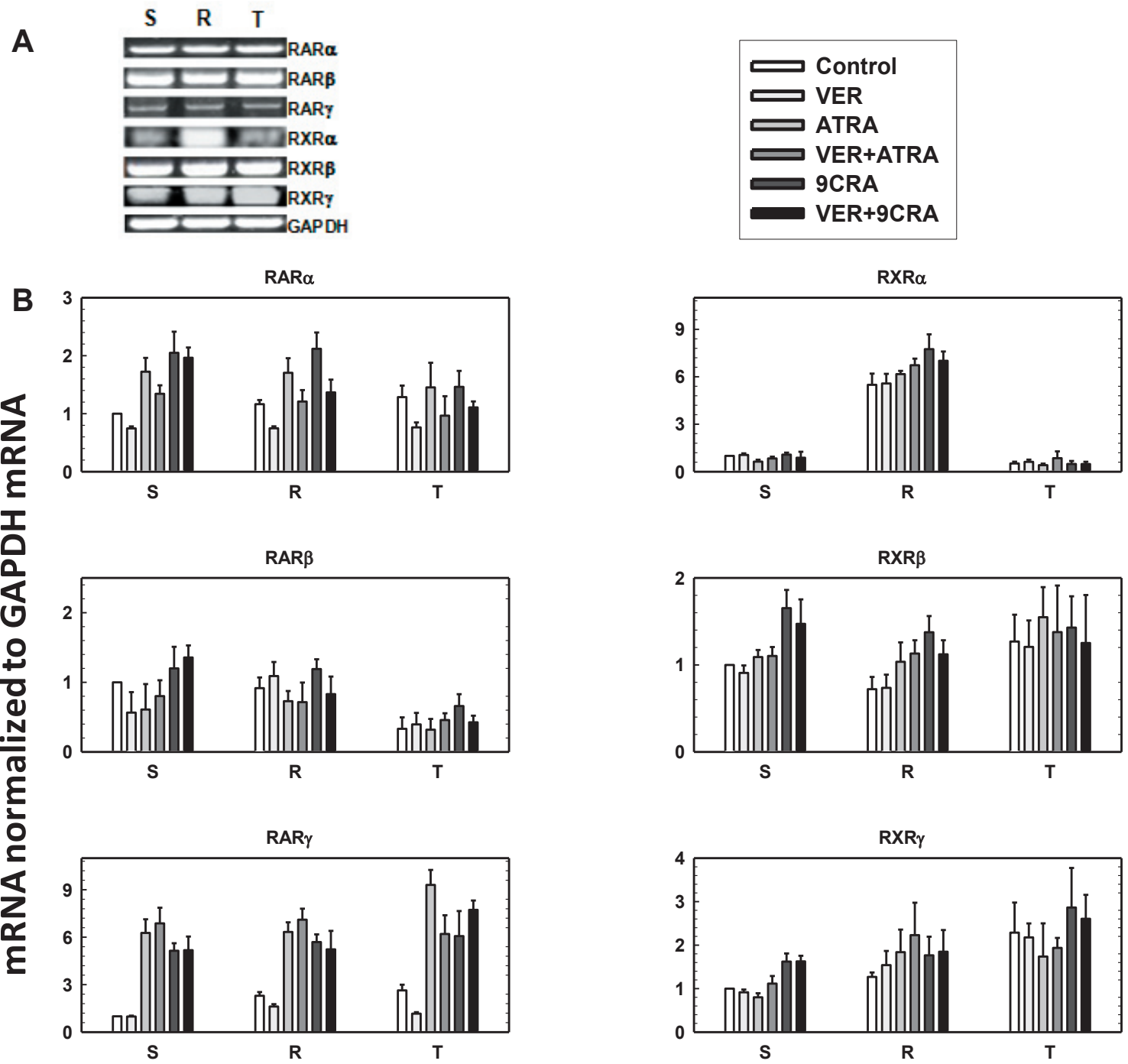

Figure 2. Expression of the RAR and RXR subtypes in the S, R and T variants of L1210 cells. Panel A: Detection of the RAR and RXR isoform transcripts by reverse transcription PCR. Data are representative of three independent experiments. Panel B: Quantification of the RAR and RXR isoform transcripts by real-time reverse transcription PCR using the same primers. Data represent the mean \pm SD of five independent experiments.VER was used at a concentration of $10 \mu \mathrm{mol} / \mathrm{l}$. AtRA and 9cRA were used at a concentration of $3.3 \mu \mathrm{mol} / \mathrm{l}$. For other details, see the Materials and Methods section. 
The expression of RXR $\beta$ was significantly lower in the $R$ cells compared with the $S$ and T cell variants $(p<0.001$; Fig. $2, \mathrm{RXR} \beta$ ). In contrast to VER alone, which had no effect on the RXR $\beta$ transcript level in all L1210 cell variants, AtRA alone induced a more pronounced expression of this receptor in the $\mathrm{S}(\mathrm{p}<0.05)$ and $\mathrm{R}(\mathrm{p}<0.01)$ cells. This increase in the expression of this receptor was also observed in the $\mathrm{T}$ cells but was insignificant. While a significant induction of RXR $\beta$ expression was found after treatment with $9 \mathrm{cRA}$ in the $\mathrm{S}$ and $\mathrm{R}$ cells ( $\mathrm{p}<0.001$; Fig. 2, RXR $\beta$ ), combined treatment with 9cRA and VER showed a reduction in RXR $\beta$ gene transcription in all L1210 cell variants when compared to cells treated with 9cRA alone. However, this change was only found to be significant in the R cells ( $p<0.05$; Fig. $2, \operatorname{RXR} \beta$ ). The RXR $\beta$ mRNA level was still significantly higher than that observed in the $\mathrm{R}$ cells treated with VER alone ( $<<0.001$; Fig. $2, \mathrm{RXR} \beta$ ).

Both P-gp-positive L1210 cell variants expressed RXR $\gamma$ at a significantly higher level $(p<0.05$ and $p<0.001)$ than the
S cells (Fig. 2, RXR $\gamma$ ). VER alone did not induce significant effects on the transcription of this nuclear receptor in all three variants. AtRA slightly inhibited the expression of RXR $\gamma$ in the $S$ cells $(p<0.05$; Fig. $2, \operatorname{RXR} \gamma)$ and, in contrast, induced its expression in the $\mathrm{R}$ cells $(\mathrm{p}<0.05$; Fig. $2, \mathrm{RXR} \gamma)$. In the $\mathrm{T}$ cells, a slight depression in the expression of this isoform was observed, but it was insignificant. An increase in RXR $\gamma$ transcription was detected in all L1210 cell variants after treatment with AtRA and VER together in comparison with treatment with AtRA alone, but this change was only significant in the $S$ cells $(\mathrm{p}<0.01$; Fig. $2, \mathrm{RXR} \gamma)$. Treatment with $9 \mathrm{cRA}$ induced the expression of RXR $\gamma$ only in the P-gp-negative $\mathrm{S}$ cells $(\mathrm{p}<0.01)$ but not in either of the P-gp-positive cell lines ( $\mathrm{R}$ or T). Treatment with both 9cRA and VER did not alter RXR $\gamma$ transcription from the values observed after treatment with 9cRA alone in all three variants.

Effect of AtRA or 9cRA alone and in combination with VER on the expression of P-gp in $R$ and $T$ cells. The high

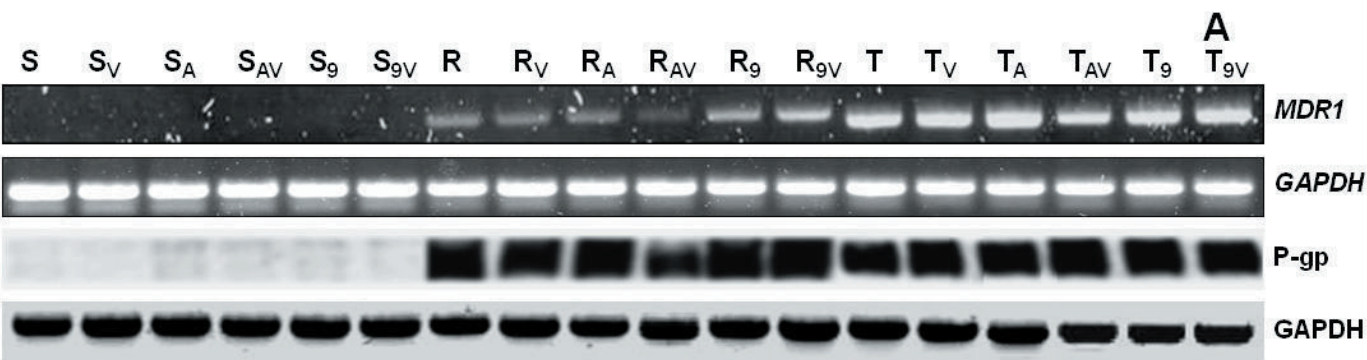

B
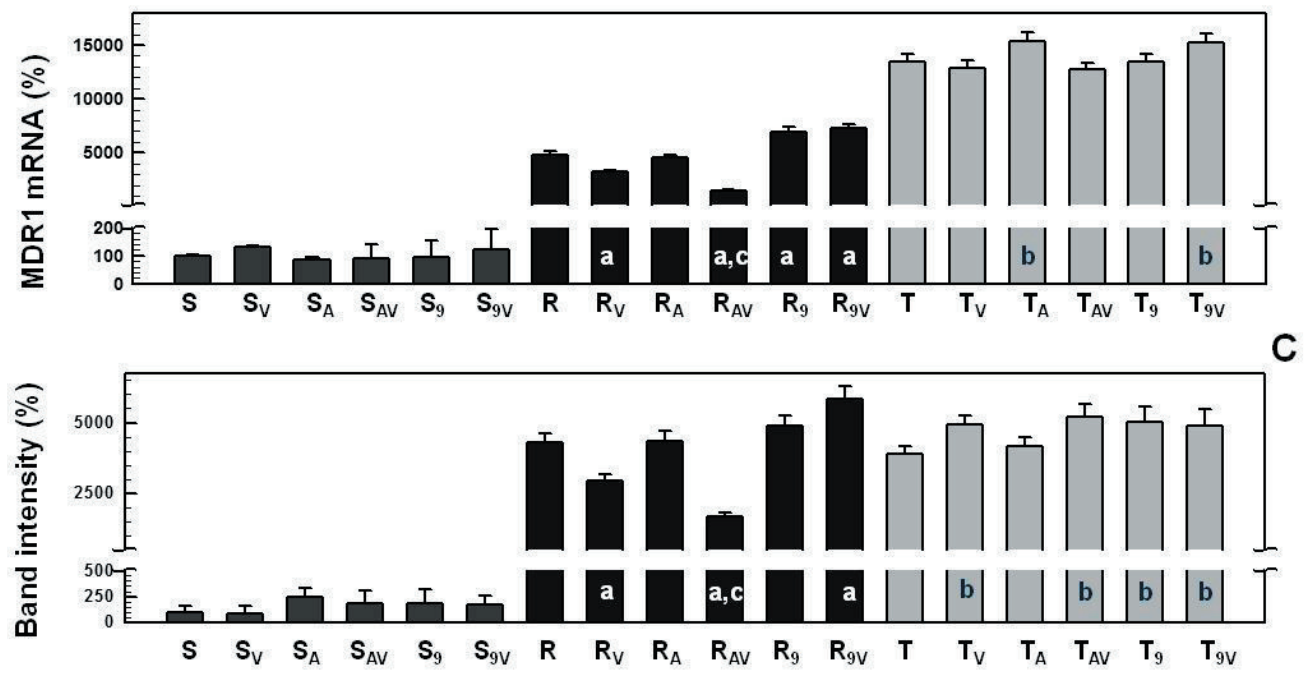

Figure 3. Effect of treatment with VER (V), AtRA (A) and 9cRA (9) on the expression of P-gp in S, R and T cells. Panel A: Detection of MDR1 gene transcription by RT-PCR and P-gp protein content by western blot analysis. The GAPDH gene transcript and GAPDH protein were used as internal standards. Data are representative of three independent measurements. Panel B: Quantification of MDR1 gene transcription by quantitative RT-PCR. The MDR1 mRNA levels were normalized to those of GAPDH mRNA. The value obtained for the normalized MDR1 mRNA level in untreated S cells was arbitrarily chosen as $\mathbf{1 0 0 \%}$. Data represent the means \pm SD of three independent measurements. Panel C: Quantification of the P-gp protein content from the western blots by densitometry. Data represent the means $\pm \mathrm{SD}$ of 3 independent measurements. VER was used at a concentration of $10 \mu \mathrm{mol} / \mathrm{l}$. AtRA and 9cRA were used in at a concentrations of $3.3 \mu \mathrm{mol} / \mathrm{l}$. Statistical significance: $a$-different from the value obtained in $R$ cells at $p<0.05$; $b-$ different from the value obtained in $\mathrm{T}$ cells $\mathrm{p}<0.05 ; \mathrm{c}$ - different from the value obtained in $\mathrm{R}_{\mathrm{v}}$ cells $\mathrm{p}<0.05$. For other details, see the material and Methods. 
expression of P-gp in the R and T cells at the mRNA and protein level was detected by reverse transcription PCR and western blot analysis (with the c219 antibody), as shown in Fig. 3 (panel A). The gene transcripts or P-gp protein gave no or very weak signal in the $S$ cells, and no remarkable change in their content was registered after the treatment of these cells with VER, AtRA or 9cRA alone or the combined treatment of AtRA or 9cRA with VER (Fig. 3, panel A).Treatment of the $\mathrm{R}$ and $\mathrm{T}$ cells with AtRA or 9cRA alone or in combination with VER induced several changes in P-gp expression. Quantification of the $\mathrm{mRNA}$ level in the respective sample was checked by quantitative RT-PCR, and quantification of P-gp in the western blot bands was ascertained by densitometry. For details, see the Experimental section.

AtRA alone did not induce changes in the expression of $\mathrm{P}$-gp at either the mRNA or protein level in the R cells (Fig. 3 , panels $\mathrm{B}$ and $\mathrm{C}$ ). However, treatment of the $\mathrm{R}$ cells with VER alone induced a significant decrease in P-gp expression at both levels. A more pronounced downregulation of P-gp expression was visible in the $\mathrm{R}$ cells after combined treatment with AtRA and VER at both the mRNA and protein level (Fig. 3, panels $A$ and $B$ ).

In contrast to AtRA alone, which did not affect P-gp expression, 9cRA alone significantly elevated P-gp gene transcription in the R cells (Fig. 3, panel B).

While a small increase in P-gp content was visible by western blot analysis after treatment of the R cells with 9cRA, this change failed to meet our criteria for statistical significance (Fig. 3, panel C). The combined treatment of $\mathrm{R}$ cells with 9cRA and VER induced a significant upregulation of P-gp expression at the mRNA and protein level compared with the values obtained for untreated R cells (Fig. 3, panels B and C). A small but significant elevation of P-gp expression at the mRNA level was achieved after the treatment of the T cells with AtRA alone and with 9cRA together with VER when compared with the levels of the untreated T cells. Higher P-gp protein levels were

A
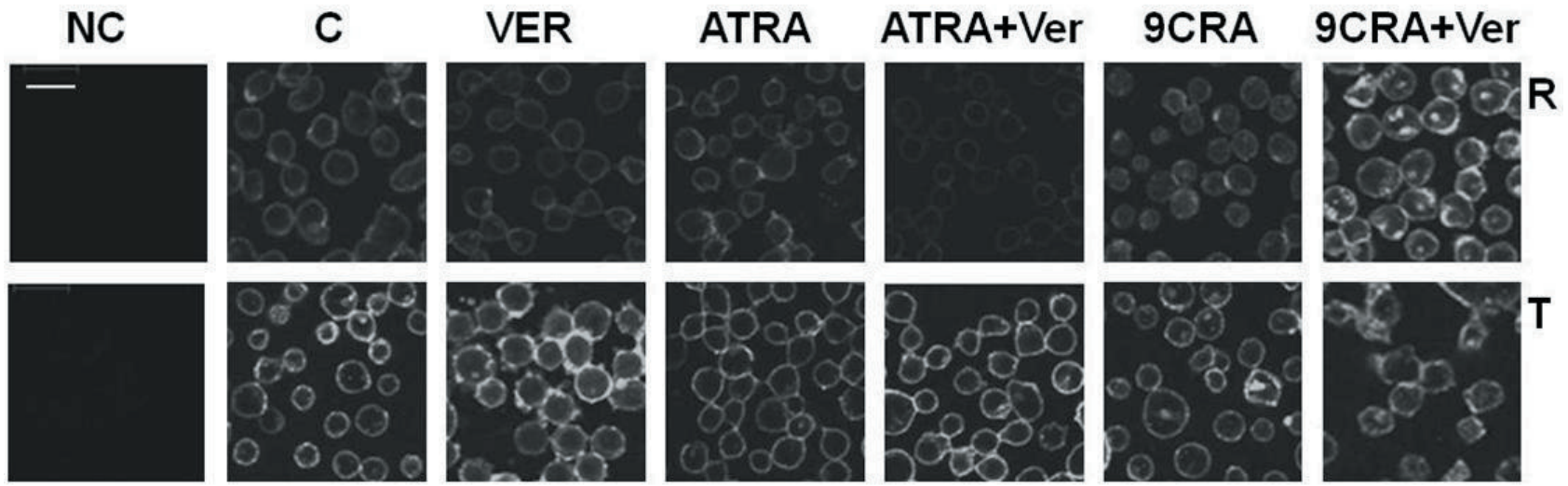

B

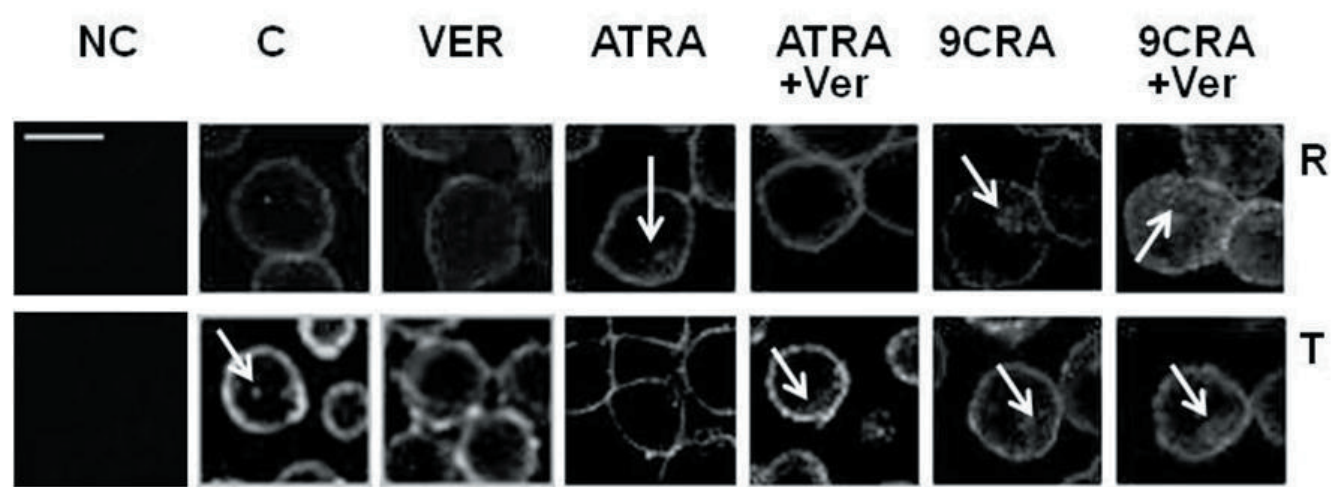

Figure 4.Visualization of P-gp localization in R and T cells by immunofluorescence confocal microscopy with the c219 anti-P-gp antibody and a FITClabeled anti-mouse IgG secondary antibody. The $R$ and $T$ cells were examined without treatment $(C)$ and after treatment with VER, AtRA, AtRA+VER, 9cRA and 9cRA+VER. The negative control (NC) represents $R$ and $T$ cells without treatment and without the anti-P-gp antibody during sample preparation. Panel A lower magnification white abscissa is equal $40 \mu \mathrm{m}$, panel B higher magnification the white abscissa is equal $20 \mu \mathrm{m}$. Arrows in panel $B$ indicated intracellularly localized immunoreactivity. The data are representative of three independent measurements. 
observed in the T cells treated with VER alone, 9cRA alone, and the combination of each retinoic acid isomer with VER than in the untreated T cells (Fig. 3, panels B and C).

Effect of AtRA, 9cRA and VER on P-gp localization in $S, R$ and T cells. P-gp was found to be predominantly localized at the cell surface of the $\mathrm{R}$ and $\mathrm{T}$ cells, where it formed a compact surface layer that is visible by immunocytochemistry with the c219 anti-P-gp antibody (Fig. 4A). No detectable $\mathrm{P}$-gp signal could be found in the $\mathrm{S}$ cells when the same protocol was used $[15,35]$. A small amount of P-gp was also localized in the intracellular space of the $\mathrm{R}$ and $\mathrm{T}$ cells (Fig. 4B). Treatment with VER induced a visible decrease in P-gp content in the R cells (Fig.4A). In contrast, the same treatment of $\mathrm{T}$ cells induced an increase in P-gp at both the plasma membrane and in the intracellular space. These changes in the P-gp cellular content are consistent with the results of our western blot quantification shown in Fig. 3 (panel C). AtRA alone did not induce remarkable changes in the P-gp content in the $\mathrm{T}$ and $\mathrm{R}$ cells by immunocytochemistry (Fig. 4A). However, when AtRA was used together with VER, a remarkable decrease in P-gp content was visible in the R cells compared with their untreated counterparts (Fig. 4A). In contrast, with the same treatment, the T cells were found to contain a similar amount of P-gp between the treated and untreated cells. Treatment with $9 \mathrm{cRA}$ alone or in combination with VER increased the P-gp cellular content (Fig. 4A), particularly the subfraction localized in the intracellular space (Fig. 4B).
A
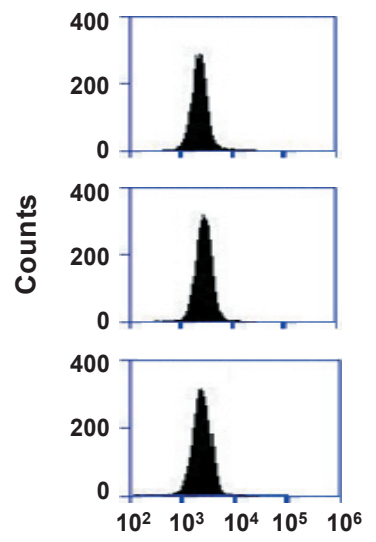

Calcein fluorescence intensity

\section{C}

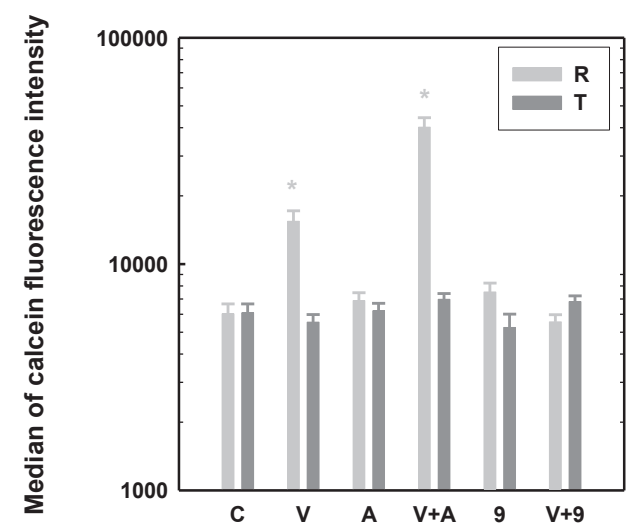

Calcein
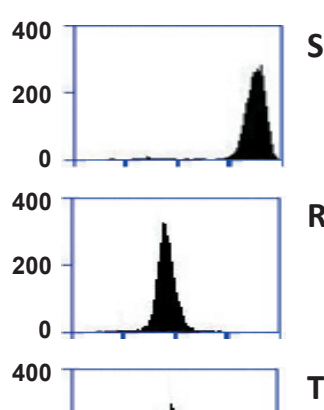

$\mathbf{T}$

$S$

$\mathbf{R}$
B

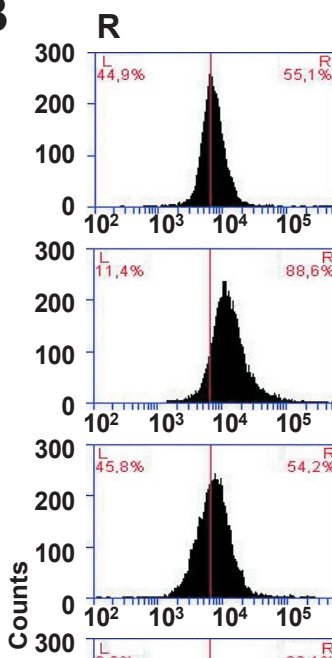

Control

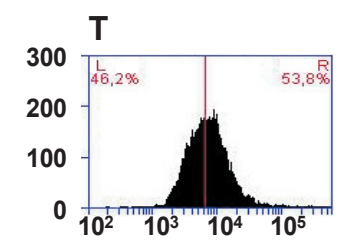

VER

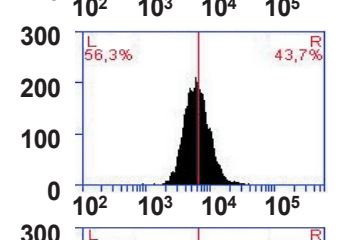

ATRA
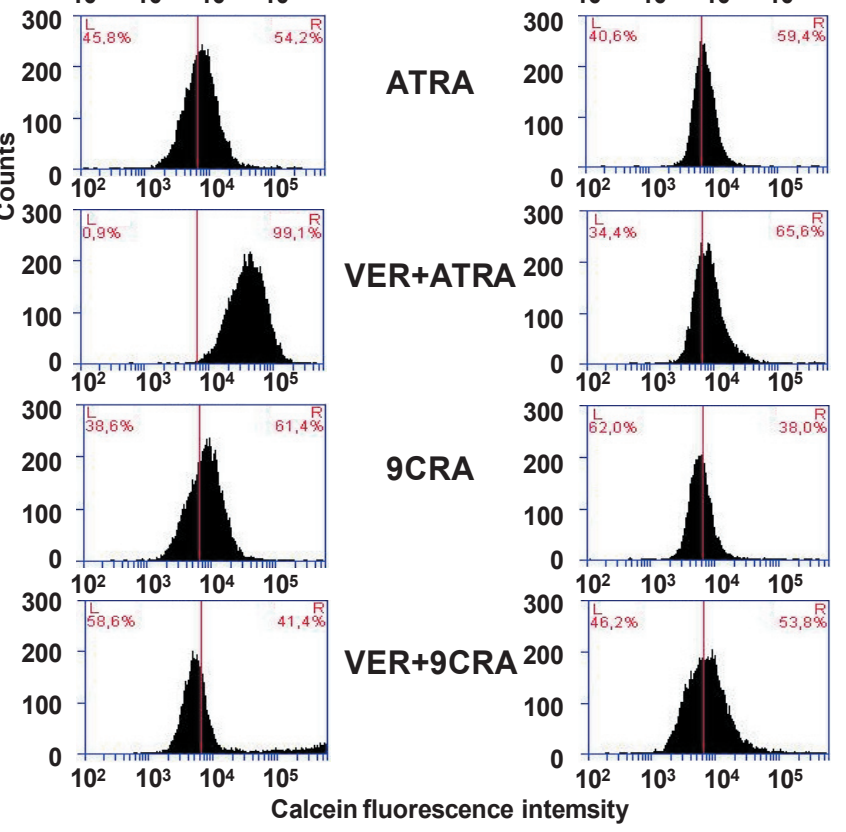

Figure 5. Estimation of P-gp efflux activity in $\mathrm{R}$ and $\mathrm{T}$ cells by calcein/AM retention assay. Only the propidium iodide-negative cells were counted. The proportion of cells stained with propidium iodide never exceeded $6 \%$ of the total cells counted. Panel A: Comparison of calcein retention in the $S$, $R$ and T cells. Samples were prepared without and with calcein/AM. The data are representative of three independent measurements. Panel B: Effect of treatment with VER, AtRA, VER+AtRA, 9cRA and VER+9cRA on calcein retention within $\mathrm{R}$ and T cells. The text in graph denotes the proportion (in \%) of cells counted in the left $(\mathrm{L})$ and right $(\mathrm{R})$ halves of each graph. The data are representative of three independent measurements. Panel $\mathrm{C}$ : Median fluorescence intensity of calcein in the R and T cells after treatment with VER (V), AtRA (A), VER and AtRA (V+A), 9cRA (9) and VER and 9cRA (V+9) in comparison their untreated counterparts $(C)$. Data represent the means \pm SD of three independent measurements. Asterisks $\left({ }^{*}\right)$ denote significant differences from the untreated control at $\mathrm{p}<0.001$. 
Effect of AtRA, 9cRA and VER on P-gp efflux in S, R and T cells. In its esterified form, calcein/AM, an intracellular calcium indicator, represents a suitable substrate for P-gp, and active P-gp blocks its intracellular entry. However, after intracellular deesterification, liberated calcein is no longer transportable by P-gp [35]. Thus, in P-gp-positive cells, the efflux activity of this transporter blocks intracellular calcein retention. The decrease in calcein retention has often been used as a measure of drug efflux activity present at plasma membrane of MDR cells and, in the case of P-gp, may be antagonized by P-glycoprotein inhibitors, such as VER and cyclosporine A [41]. The ability of both of these P-gp inhibitors to restore calcein retention in $\mathrm{R}$ and $\mathrm{T}$ cells was proven in previous reports $[28,35,39]$. While a massive retention of calcein was visible in the $S$ cells, the calcein signals were much less pronounced in the $\mathrm{R}$ and $\mathrm{T}$ cells (Fig. $5 \mathrm{~A}$ ). Improvements in calcein retention were observed when the $\mathrm{R}$ cells were treated with VER alone and VER in combination with AtRA. The treatment of the R cells with AtRA alone, 9cRA alone and VER together with 9cRA did not significantly alter the calcein retention in these cells. When the T cells were treated similarly to the R cells, no significant alterations in calcein retention were observed. Thus, the depressed retention of calcein documented in Fig. 5A for the $\mathrm{R}$ and $\mathrm{T}$ cells compared to the $\mathrm{S}$ cells represents a measurable marker of P-gp efflux activity in these cells.

\section{Discussion}

AtRA at the micromolar concentrations induced slight but significant depression of $\mathrm{S}, \mathrm{R}$ and $\mathrm{T}$ cell viabilities (Fig. 1). This effect seems to be less pronounced in $\mathrm{R}$ and $\mathrm{T}$ cells than in $S$ cells. In contrast, 9cRA at the same concentration was not found to induce any significant affect on $S, R$ and $T$ cells viability. Slightly stronger effects of AtRA than 9cRA on the viability of Thybridoma cells were documented elsewhere [52]. The application of AtRA or 9cRA together with known inhibitors of P-gp (VER, cyclosporine A and ketoconazole) did not significantly alter the viability of the $\mathrm{R}$ and $\mathrm{T}$ cells compared with the effects of AtRA or 9cRA alone (data not shown). This finding is consistent with previously published data that retinoic acid is not substrate for P-gp $[38,47]$.

In the present paper, we provide evidence that the overexpression of P-gp in L1210 cells induced several changes in specific transcription of both subgroups of nuclear receptors for vitamin A derivatives:

- First, when L1210 cells were exposed to selective pressure with VCR (which results in the production of R cells [31]), an increase in the RAR $\gamma(\mathrm{p}<0.001), \operatorname{RXR} \alpha(\mathrm{p}<0.001)$ and $\operatorname{RXR} \gamma(\mathrm{p}<0.05)$ transcript levels were observed (Fig. 2). In contrast, a significant downregulation of RXR $\beta$ expression $(p<0.001)$ was observed in this variant. Based on these findings, we can assume that the adaptation of drug-sensitive cells to VCR predominantly interferes in RXR-mediated pathways, particularly RXRa-mediated pathways. Because
RXRs are heterodimerization partners for multiple nuclear receptors, the P-gp-mediated VCR resistance found in $\mathrm{R}$ cells could be associated with various alterations in cell regulatory mechanisms. To understand the meaning of these facts future detailed study of effects induced by VCR on expressions and functions of RXR and their partner nuclear receptors will be necessary.

- Second, when the S cells were transfected with the human P-gp gene (which results T cells [39]), an induction in RARa $(\mathrm{p}<0.05), \operatorname{RAR} \gamma(\mathrm{p}<0.001)$ and RXR $\gamma(\mathrm{p}<0.001)$ transcription was observed (Fig. 2). In contrast, a significant reduction in $\operatorname{RXR} \alpha(\mathrm{p}<0.01)$ and $\operatorname{RAR} \beta(\mathrm{p}<0.01)$ expression was observed in this cell variant.

Despite widely accepted role of P-gp as drug efflux pump, this protein, appears to augment cell survival via another drug-efflux independent role that involves modulation of the apoptotic pathway $[6,29]$. This is consistent with fact that expression of drug transport defective mutant of P-gp in CEM lymphoma cells suppresses VCR-induced apoptosis because of reduced mitochondrial cytochrome $\mathrm{C}$ release and caspase activation [45]. We have reported robust activation of caspase3 and down-regulation of the anti-apoptotic Bcl-2 protein in $S$ cells after treatment with cisplatin, which is a non-substrate for P-gp [15]. The activation of caspase- 3 and down-regulation of $\mathrm{Bcl}-2$ were less prominent in P-gp-positive cell variants $\mathrm{R}$ and T. P-gp-was recently described to alter p53 function through direct interaction between p53 and P-gp detected by immunoprecipitation [17]. Above facts indicate that P-gp, independent of its drug efflux activity, induced changes in cell regulatory pathways that confer a partial loss of sensitivity also to drugs, which are not P-gp substrates. Changes of cell regulatory pathways induced by P-gp could be connected also with alterations in expressions and functions of nuclear receptors including RAR and RXR, which we plan to study in future experiments.

While S cells contain only negligible amounts of P-gp mRNA and protein, which can be hardly detected by reverse transcription PCR and western blot, massive amounts of this transcript and protein were documented in both drug-resistant cell lines (Fig. 3). This is consistent with findings described in previous papers $[15,34,35,39]$.

The fact that PXR is involved in the regulation of P-gp expression and that this nuclear receptor binds to DNA after dimerization with one of the RXR isoforms [20,22] indicates the possibility that a functional crosstalk exists between the regulatory pathways of the nuclear receptors for vitamin A derivatives and the MDR phenotype [40]. Using four leukemia cell lines that were stably transfected with RAR [37] showed that AtRA increases the expression and activity of P-glycoprotein through RAR a via different mechanisms in different cells. However, we found that the combined treatment of AtRA and VER downregulated the expression and efflux activity of P-gp in the $\mathrm{R}$ cell variant [38].

While AtRA alone did not alter cell contents of P-gp mRNA or protein in the R cells (Fig. 3), treatment of these cells with 
VER alone induced a significant decrease in P-gp expression at both levels. Consistent with this finding, the downregulation of P-gp expression at the mRNA and protein level after treatment with VER has been previously described [38, 46]. The exact mechanism of this downregulation is not known, but it could be deduced from the fact that VER inhibits NF- $\kappa$ $B$ activation [23]. Activation of this nuclear factor increases the expression of P-glycoprotein $[4,50]$.

Combined treatment with AtRA and VER induced a more pronounced downregulation of $\mathrm{P}$-gp expression visible in the R cells at both the mRNA and protein level (Fig. 3). This result indicated that AtRA is only able to decrease P-gp expression in $\mathrm{R}$ cells when VER is present during treatment. This activity of VER could not be addressed to its known inhibitory activity against P-gp-mediated efflux because AtRA is not a substrate for P-gp and VER fails to alter the uptake of AtRA by P-gppositive cells [38]. However, VER was described as an inhibitor of the cytochrome P450 (CYP) family, particularly the CYP3A subfamily [27]. Moreover, members the CYP3A subfamily have been described as enzymes that can modify AtRA to several oxidized metabolites of retinoic acid [24, 53]. Thus, VER, via the blockade of CYP3A and most likely other CYP isoenzyme activities, may prevent AtRA modification, enabling AtRA to interact effectively with RAR and induce its effects on P-gp expression [40]. The ability of AtRA to downregulate P-gp expression can be explained by the physical hindrance of RAR receptors activated with AtRA, preventing the nuclear receptors that induce $\mathrm{P}$-gp transcription (i.e., PXR) from effectively dimerizing with RXR [40]. Another mechanism by which AtRA may depress P-gp expression is given from study of P-gp promoter function. Site-directed mutagenesis of the AP-1 binding site (binding site for the transcription factor activation protein 1), which is located at -48 base pairs, revealed its crucial role in full $\mathrm{P}$-gp promoter activity [49]. The same authors showed that cotransfection of P-gp promoter with RAR $\alpha$ or RAR $\beta$ and supplementation with retinoic acid inhibits approximately 75 to $80 \%$ of P-gp promoter activity. RARs inhibit AP1 activation by regulating the extracellular signal-regulated kinase (ERK) pathway and by recruiting the CREB binding protein to an AP1-responsive promoter [3]. The important role of the ERK pathway can be deduced from the fact that inhibitors of this pathway (PD98059 and UO126) reverse P-gp-mediated MDR [21].

The data shown in Fig. 3 suggest that $\mathrm{R}$ and $\mathrm{T}$ cells respond differently to the various treatments with AtRA, 9cRA and VER. Namely, the downregulation of P-gp expression in $R$ cells upon treatment with VER alone and with AtRA and VER together represents a typical feature of $\mathrm{R}$ cells, i.e., cells that express P-gp from a gene located in the L1210 cell genome under natural control of gene transcription. In T cells, which overexpress P-gp from plasmid DNA, the same treatments did not induce a similar response on P-gp expression. Therefore, the downregulation of P-gp upon treatment with VER or VER and AtRA that was documented for the R cells at the mRNA and protein levels (Fig. 3) could be considered an intrinsic property of transcriptional regulation of P-gp in the L1210 genome.

In contrast to AtRA, 9cRA in combination with VER was found to elevate P-gp expression in R cells and, to a smaller extent, in T cells (Fig. 3). Changes in P-gp cell contents documented on western blot (Fig. 3) are consistent with alterations in amount of immune-reactive material detected with c219 antibody by immunofluorescence (Fig. 4). While majority of P-gp is localized on R and T cell surface small amount of this protein was also localized in the intracellular space of the $\mathrm{R}$ and $\mathrm{T}$ cells (Fig. 4). The intracellular localization of P-gp, particularly in the nuclear envelope [43] and mitochondria [36], have already been described. Interestingly, 9cRA alone or in combination with VER, which induced increase of P-gp cell content (Fig. 3) induced also an increase in the proportion of intracellular localized P-gp (Fig. 4). The meaning of this change in P-gp localization should be explored in future studies.

In its esterified form, calcein/AM, an intracellular calcium indicator, represents a suitable substrate for P-gp, and active P-gp blocks its intracellular entry. However, after intracellular deesterification, liberated calcein is no longer transportable by P-gp [35]. Thus, in P-gp-positive cells, the efflux activity of this transporter blocks intracellular calcein retention. The decrease in calcein retention has often been used as a measure of drug efflux activity present at plasma membrane of MDR cells and, in the case of P-gp, may be antagonized by P-glycoprotein inhibitors, such as VER and cyclosporine A [41]. The ability of both of these P-gp inhibitors to restore calcein retention in $\mathrm{R}$ and $\mathrm{T}$ cells was proven in previous reports [28, 35, 39]. Thus, the depressed retention of calcein documented in Fig. $5 \mathrm{~A}$ for the $\mathrm{R}$ and $\mathrm{T}$ cells compared to the $\mathrm{S}$ cells represents a measurable marker of P-gp efflux activity in these cells.

Both of the P-gp-positive L1210 cell variants exert strong resistance to VCR in comparison with $\mathrm{S}$ cells $[11,35]$. This drug is known to upregulate the expressions of $\mathrm{P}$-gp and others $\mathrm{ABC}$ transporters as well as members of CYP3A family via activation of pregnane $\mathrm{X}$ receptors (reviewed in [7]).While several of the changes in P-gp expression at the mRNA or protein level after the different treatments of the $\mathrm{R}$ and $\mathrm{T}$ cells were statistically significant, the alterations of P-gp transport function were observed only after treatment of R cells with VER alone or VER in combination with ATRA (Fig. 5). Elevated amounts of P-gp after treatment of $\mathrm{R}$ and $\mathrm{T}$ cells with 9cRA alone or in combination with VER (Fig. 3) retains probably in intracellular structures (Fig. 4) and therefore cannot improve protection of cells against calcein retention (Fig. 5).

\section{Conclusion}

Treatment with VER alone induced the downregulation of P-gp expression, membrane localization and efflux activity in $\mathrm{R}$ cells but oppositely an increase of P-gp protein in $\mathrm{T}$ cells. The combined treatment of $\mathrm{R}$ cells with VER and AtRA induced more pronounced decrease of $\mathrm{P}$-gp expression at both the mRNA and protein level as induced VER alone 
(Fig. 3). This reflects the smaller amount of this protein in the plasma membrane (Fig. 4) and the consequent decrease in the P-gp efflux activity in this cell variant when compared with its untreated counterpart (Fig. 5). Treatment of T cells with VER and AtRA did not alter the P-gp protein level from value obtained for VER alone (Fig. 3). The changes of P-gp contents in T cells induced by VER and ATRA were not associated with changes in P-gp efflux activity (Fig. 5). The downregulation of P-gp in R cells after treatment with VER alone and VER in combination with AtRA must involve alterations in the regulation of P-gp expression in the L1210 cell genome because in T cells, which express human P-gp from the pHaMDRwt plasmid, i.e., with a totally different mechanism of P-gp transcriptional induction from R cells, similar effects were not observed.

In contrast to treatment with AtRA and VER, combined treatment with 9cRA and VER was found to elevate P-gp expression in R cells and, to a smaller extent, in T cells (Fig. 3 and 4). Moreover, treatment of both P-gp positive cell variants with 9cRA alone or in combination with VER induced an elevation of P-gp localized in intracellular space of cells. AtRA in contrast to 9cRA (known as agonist of both RXR and RAR receptors) is known to interact with RARs exclusively [18]. Therefore, downregulation of P-gp content/activity in $\mathrm{R}$ cells observed after treatment with VER and AtRA together seems to be connected with AtRA induced activation of RAR regulatory pathway.

Acknowledgments: This research was supported by grants from the Slovak grant agencies: APVV grant agency No.: APVV-02-9010, APVV-0160-11, VEGA grant agency No.: Vega 2/0008/11, Vega $2 / 0100 / 12$, Vega 2/0182/13 and by project of Development of Competence Centre for research and development in molecular medicine" ITMS 26240220071.

\section{References}

[1] ASOU N. All-trans retinoic acid in the treatment of acute promyelocytic leukemia. Intern Med 2007; 46: 91-3. http:// dx.doi.org/10.2169/internalmedicine.46.1780

[2] BATES SE, MICKLEY LA, CHEN YN, RICHERT N, RUDICK $\mathrm{J}$ et al. Expression of a drug resistance gene in human neuroblastoma cell lines: modulation by retinoic acid-induced differentiation. Mol Cell Biol 1989; 9: 4337-44.

[3] BENKOUSSA M, BRAND C, DELMOTTE MH, FORMSTECHER P, LEFEBVRE P. Retinoic acid receptors inhibit AP1 activation by regulating extracellular signal-regulated kinase and $\mathrm{CBP}$ recruitment to an AP1-responsive promoter. Mol Cell Biol 2002; 22: 4522-34. http://dx.doi.org/10.1128/ MCB.22.13.4522-4534.2002

[4] BENTIRES-ALJ M, BARBU V, FILLET M, CHARIOT A, RELIC B et al. NF-kappaB transcription factor induces drug resistance through MDR1 expression in cancer cells. Oncogene 2003; 22: 90-7. http://dx.doi.org/10.1038/sj.onc.1206056

[5] BREIER A, BARANCIK M, SULOVA Z, UHRIK B P-glycoprotein--implications of metabolism of neoplastic cells and cancer therapy. Curr Cancer Drug Targets 2005; 5: 457-68. http://dx.doi.org/10.2174/1568009054863636

[6] BREIER A, GIBALOVA L, SERES M, BARANCIK M, SULOVA Z New insight into p-glycoprotein as a drug target. Anticancer Agents Med Chem 2013; 13: 159-70. http://dx.doi. org/10.2174/187152013804487380

[7] BREIER A, IMRICHOVA D, PAULIKOVA H, BARANCIK $M$, SULOVA Z. Vincristine as an inductor of drug resistance marker expression in neoplastic cells. In: Coello JM, Sabres YD, Eds. Vincristine: Clinical Uses, Pharmacokinetics and Impacts on Health: Nova Science Publishers, 2013: pp 1-31; online on: https: //www.novapublishers.com/catalog/product_info.php?products_id=46763.

[8] BRTKO J, THALHAMER J Renaissance of the biologically active vitamin A derivatives: established and novel directed therapies for cancer and chemoprevention. Curr Pharm Des 2003; 9: 2067-77. http://dx.doi.org/10.2174/ $\underline{1381612033454144}$

[9] BRTKO J, DVORAK Z Role of retinoids, rexinoids and thyroid hormone in the expression of cytochrome p450 enzymes. Curr Drug Metab 2011; 12: 71-88. http://dx.doi. org/10.2174/138920011795016881

[10] BRUSERUD O, GJERTSEN BT, HUANG T Induction of differentiation and apoptosis- a possible strategy in the treatment of adult acute myelogenous leukemia. Oncologist 2000; 5: 454-62. http://dx.doi.org/10.1634/theoncologist.5-6-454

[11] BUBENCIKOVA T, CHOLUJOVA D, MESSINGEROVA L, MISLOVICOVA D, SERES $M$ et al. Detection of glycomic alterations induced by overexpression of p-glycoprotein on the surfaces of L1210 cells using sialic acid binding lectins. Int J Mol Sci 2012; 13: 15177-92. http://dx.doi.org/10.3390/ ijms131115177

[12] DONG D, NOY N Heterodimer formation by retinoid X receptor: regulation by ligands and by the receptor's self-association properties. Biochemistry 1998; 37: 10691-700. http://dx.doi. org/10.1021/bi980561r

[13] GALLAGHER RE Retinoic acid resistance in acute promyelocytic leukemia. Leukemia 2002; 16: 1940-58. http://dx.doi. org/10.1038/sj.leu.2402719

[14] GERLIER D, THOMASSET N Use of MTT colorimetric assay to measure cell activation. J Immunol Methods 1986; 94: 57-63. http://dx.doi.org/10.1016/0022-1759(86)90215-2

[15] GIBALOVA L, SERES M, RUSNAK A, DITTE P, LABUDOVA $\mathrm{M}$ et al. P-glycoprotein depresses cisplatin sensitivity in L1210 cells by inhibiting cisplatin-induced caspase-3 activation. Toxicol In Vitro 2012; 26: 435-44. http://dx.doi.org/10.1016/ j.tiv.2012.01.014

[16] GRANDJEAN - FORESTIER F, STENGER C, ROBERT J, VERDIER M, RATINAUD M-H, The p-glycoprotein 170: just a multidrug resistance protein or a protean molecule? John Wiley \& Sons, Inc.: 2009; p 18-46.

[17] HE S, LIU F, XIE Z, ZU X, XU W et al. P-Glycoprotein/MDR1 Regulates Pokemon Gene Transcription Through p53 Expression in Human Breast Cancer Cells. Int J Mol Sci 2010; 11: 3309-051. http://dx.doi.org/10.3390/ijms11093039

[18] HORN V, MINUCCI S, OGRYZKO VV, ADAMSON ED, HOWARD BH et al. RAR and RXR selective ligands 
cooperatively induce apoptosis and neuronal differentiation in P19 embryonal carcinoma cells. FASEB J 1996; 10: 1071-7.

[19] CHIKAMORI K, HILL JE, GRABOWSKI DR, ZARKHIN E, GROZAV AG et al. Downregulation of topoisomerase IIbeta in myeloid leukemia cell lines leads to activation of apoptosis following all-trans retinoic acid-induced differentiation/growth arrest. Leukemia 2006; 20: 1809-18. http://dx.doi. org/10.1038/sj.leu.2404351

[20] IHUNNAH CA, JIANG M, XIE W Nuclear receptor PXR, transcriptional circuits and metabolic relevance. Biochim Biophys Acta 2011; 1812: 956-63. http://dx.doi.org/10.1016/ j.bbadis.2011.01.014

[21] KISUCKA J, BARANCIK M, BOHACOVA V, BREIER A Reversal effect of specific inhibitors of extracellular-signal regulated protein kinase pathway on P-glycoprotein mediated vincristine resistance of L1210 cells. Gen Physiol Biophys 2001; 20: 439-44.

[22] KRUGER KA, BLUM JW, GREGER DL Expression of nuclear receptor and target genes in liver and intestine of neonatal calves fed colostrum and vitamin A. J Dairy Sci 2005; 88: 3971-81. http://dx.doi.org/10.3168/jds.S0022-0302(05)730836

[23] LI G, QI XP, WU XY, LIU FK, XU Z et al. Verapamil modulates LPS-induced cytokine production via inhibition of NF-kappa B activation in the liver. Inflamm Res 2006; 55: 108-13. http:// dx.doi.org/10.1007/s00011-005-0060-y

[24] MARILL J, CRESTEIL T, LANOTTE M, CHABOT GG Identification of human cytochrome P450s involved in the formation of all-trans-retinoic acid principal metabolites. Mol Pharmacol 2000; 58: 1341-8.

[25] MASETTIR, VENDEMINIF, ZAMA D, BIAGIC, GASPERINI $\mathrm{P}$ et al. All-trans retinoic acid in the treatment of pediatric acute promyelocytic leukemia. Expert Rev Anticancer Ther 2012; 12: 1191-204. http://dx.doi.org/10.1586/era.12.101

[26] NAPOLI JL Physiological insights into all-trans-retinoic acid biosynthesis. Biochim Biophys Acta 2012; 1821: 152-67. http://dx.doi.org/10.1016/j.bbalip.2011.05.004

[27] NEUVONEN PJ, NIEMI M, BACKMAN JT Drug interactions with lipid-lowering drugs: mechanisms and clinical relevance. Clin Pharmacol Ther 2006; 80: 565-81. http://dx.doi. org/10.1016/j.clpt.2006.09.003

[28] ORLICKY J, SULOVA Z, DOVINOVA I, FIALA R, ZAHRADNIKOVA A, Jr. et al. Functional fluo-3/AM assay on P-glycoprotein transport activity in L1210/VCR cells by confocal microscopy. Gen Physiol Biophys 2004; 23: 357-66.

[29] PALLIS M, RUSSELL N P-glycoprotein plays a drug-efflux-independent role in augmenting cell survival in acute myeloblastic leukemia and is associated with modulation of a sphingomyelin-ceramide apoptotic pathway. Blood 2000; 95: 2897-904.

[30] PASTAN I, GOTTESMAN MM, UEDA K, LOVELACE E, RUTHERFORD AV et al. A retrovirus carrying an MDR1 cDNA confers multidrug resistance and polarized expression of P-glycoprotein in MDCK cells. Proc Natl Acad Sci U S A 1988; 85: 4486-90. http://dx.doi.org/10.1073/ pnas.85.12.4486
[31] POLEKOVA L, BARANCIK M, MRAZOVA T, PIRKER R, WALLNER J et al. Adaptation of mouse leukemia cells L1210 to vincristine. Evidence for expression of P-glycoprotein. Neoplasma 1992; 39: 73-7.

[32] RAY WJ, BAIN G, YAO M, GOTTLIEB DI CYP26, a novel mammalian cytochrome $\mathrm{P} 450$, is induced by retinoic acid and defines a new family. J Biol Chem 1997; 272: 18702-8. http://dx.doi.org/10.1074/jbc.272.30.18702

[33] SAEKI M, KUROSE K, HASEGAWA R, TOHKIN M Functional analysis of genetic variations in the 5 -flanking region of the human MDR1 gene. Mol Genet Metab 2011; 102: 91-8. http://dx.doi.org/10.1016/j.ymgme.2010.08.019

[34] SERES M, DITTE P, BREIER A, SULOVA Z Effect of thapsigargin on P-glycoprotein-negative and P-glycoprotein-positive L1210 mouse leukaemia cells. Gen Physiol Biophys 2010; 29: 396-401. http://dx.doi.org/10.4149/gpb 2010 $04 \quad 396$

[35] SERES M, CHOLUJOVA D, BUBENCIKOVA T, BREIER A, SULOVA Z Tunicamycin depresses p-glycoprotein glycosylation without an effect on its membrane localization and drug efflux activity in 11210 cells. Int J Mol Sci 2011; 12: 7772-84. http://dx.doi.org/10.3390/ijms12117772

[36] SHEN Y, CHU Y, YANG Y, WANG Z Mitochondrial localization of P-glycoprotein in the human breast cancer cell line MCF-7/ADM and its functional characterization. Oncol Rep 2012; 27: 1535-40.

[37] STROMSKAYA TP, RYBALKINA EY, ZABOTINA TN, SHISHKIN AA, STAVROVSKAYA AA Influence of RARalpha gene on MDR1 expression and P-glycoprotein function in human leukemic cells. Cancer Cell Int 2005; 5: 15. http://dx.doi. org/10.1186/1475-2867-5-15

[38] SULOVA Z, MACEJOVA D, SERES M, SEDLAK J, BRTKO $\mathrm{J}$ et al. Combined treatment of P-gp-positive L1210/VCR cells by verapamil and all-trans retinoic acid induces downregulation of P-glycoprotein expression and transport activity. Toxicol In Vitro 2008; 22: 96-105. http://dx.doi.org/10.1016/ j.tiv.2007.08.011

[39] SUlOVA Z, DiTTE P, KURUCOVA T, POLAKOVA E, ROGOZANOVA $\mathrm{K}$ et al. The presence of P-glycoprotein in L1210 cells directly induces down-regulation of cell surface saccharide targets of concanavalin A. Anticancer Res 2010; 30: 3661-8.

[40] SUlOVA Z, BRTKO J, MACEJOVA D, BREIER A Are Nuclear Receptors for Retinoids Involved in the Control of the Expression and Activity of P-Glycoprotein? In: Cheng L-H, It Y, Eds. Retinoic Acid: Structure, Mechanisms and Roles in Disease: NOVA Publisher, 2012 pp 29-52; online on: https: //www.novapublishers.com/catalog/product_info. php?products_id=34515.

[41] SUSA M, CHOY E, YANG C, SCHWAB J, MANKIN H et al. Multidrug resistance reversal agent, NSC77037, identified with a cell-based screening assay. J Biomol Screen 2010; 15: 287-96. http://dx.doi.org/10.1177/1087057109359422

[42] SUZUKI S, KOBAYASHI H, SEKINE R, KUMAGAI M, MIKOSHIBA $M$ et al. 3,5,3'-Triiodo-L-thyronine potentiates all-trans-retinoic acid-induced apoptosis during differentiation of the promyeloleukemic cell HL-60. Endocrinology 1997; 138: 805-9. 
[43] SZAFLARSKI W, SUJKA-KORDOWSKA P, JANUCHOWSKI R, WOJTOWICZ K, ANDRZEJEWSKA $M$ et al. Nuclear localization of P-glycoprotein is responsible for protection of the nucleus from doxorubicin in the resistant LoVo cell line. Biomed Pharmacother 2013; 67: 497-502. http://dx.doi. org/10.1016/j.biopha.2013.03.011

[44] TABE Y, KONOPLEVA M, CONTRACTOR R, MUNSELL M, SCHOBER WD et al. Up-regulation of MDR1 and induction of doxorubicin resistance by histone deacetylase inhibitor depsipeptide (FK228) and ATRA in acute promyelocytic leukemia cells. Blood 2006; 107: 1546-54. http://dx.doi. org/10.1182/blood-2004-10-4126

[45] TAINTON KM, SMYTH MJ, JACKSON JT, TANNER JE, CERRUTI L et al. Mutational analysis of P-glycoprotein: suppression of caspase activation in the absence of ATPdependent drug efflux. Cell Death Differ 2004; 11: 1028-37. http://dx.doi.org/10.1038/sj.cdd.4401440

[46] TAKARA K, SAKAEDA T, TANIGAWARA Y, NISHIGUCHI K, OHMOTO N et al. Effects of $12 \mathrm{Ca} 2+$ antagonists on multidrug resistance, MDR1-mediated transport and MDR1 mRNA expression. Eur J Pharm Sci 2002; 16: 159-65. http://dx.doi. org/10.1016/S0928-0987(02)00082-9

[47] TAKESHITA A, SHINJO K, NAITO K, OHNISHI K, SUGIMOTO Y et al. Role of P-glycoprotein in all-trans retinoic acid (ATRA) resistance in acute promyelocytic leukaemia cells: analysis of intracellular concentration of ATRA. Br J Haematol 2000; 108: 90-2. http://dx.doi.org/10.1046/j.13652141.2000.01823.x

[48] TANAKA T, SUH KS, LO AM, DE LUCA LM p21WAF1/CIP1 is a common transcriptional target of retinoid receptors: pleiotropic regulatory mechanism through retinoic acid receptor (RAR)/retinoid X receptor (RXR) heterodimer and RXR/RXR homodimer. J Biol Chem 2007; 282: 29987-97. http://dx.doi. org/10.1074/jbc.M701700200
[49] TEETER LD, ECKERSBERG T, TSAI Y, KUO MT Analysis of the Chinese hamster P-glycoprotein/multidrug resistance gene pgp1 reveals that the AP-1 site is essential for full promoter activity. Cell Growth Differ 1991; 2: 429-37.

[50] THEVENOD F, FRIEDMANN JM, KATSEN AD, HAUSER IA Up-regulation of multidrug resistance P-glycoprotein via nuclear factor-kappaB activation protects kidney proximal tubule cells from cadmium- and reactive oxygen species-induced apoptosis. J Biol Chem 2000; 275: 1887-96. http://dx.doi. org/10.1074/jbc.275.3.1887

[51] TOKURA Y, SHIKAMI M, MIWA H, WATARAI M, SUGAMURA K et al. Augmented expression of P-gp/multi-drug resistance gene by all-trans retinoic acid in monocytic leukemic cells. Leuk Res 2002; 26: 29-36. http://dx.doi. org/10.1016/S0145-2126(01)00094-7

[52] TOTH B, LUDANYI K, KISS I, REICHERT U, MICHEL S et al. Retinoids induce Fas(CD95) ligand cell surface expression via RARgamma and nur77 in T cells. Eur J Immunol 2004; 34: 827-36. http://dx.doi.org/10.1002/eji.200324760

[53] WANG T, MA X, KRAUSZ KW, IDLE JR, GONZALEZ FJ Role of pregnane $\mathrm{X}$ receptor in control of all-trans retinoic acid (ATRA) metabolism and its potential contribution to ATRA resistance. J Pharmacol Exp Ther 2008; 324: 674-84. http://dx.doi.org/10.1124/jpet.107.131045

[54] Xu PQ, GONG JP [Effect of all trans retinoid acid (ATRA) on differentiation and apoptosis of HL-60 cell]. Ai Zheng 2004; 23: $118-23$.

[55] ZHANG R, BANIK NL, RAY SK Combination of all-trans retinoic acid and interferon-gamma upregulated p27(kip1) and down regulated CDK2 to cause cell cycle arrest leading to differentiation and apoptosis in human glioblastoma LN18 (PTEN-proficient) and U87MG (PTEN-deficient) cells. Cancer Chemother Pharmacol 2008; 62: 407-16. http://dx.doi. org/10.1007/s00280-007-0619-0 